\title{
Pengaruh tinggi batang bawah dan macam varietas pada sambung pucuk terhadap persentase tumbuh tanaman kelengkeng (Dimocarpus longan $\mathbf{L}$.)
}

\author{
The effect of rootstock height and kinds of varieties at the top connectivity to \\ the growth percentage of longan (Dimocarpus longanL.)
}

\author{
Nunuk Helilusiatiningsih ${ }^{1 *}$, Belinda Adeana ${ }^{1}$, Fajar Setyawan $^{1}$ \\ ${ }^{1}$ Program Studi Agroteknologi, Fakultas Pertanian, Universitas Islam Kadiri \\ *Email korespondensi: nunukhelilusi@gmail.com
}

Diterima: 11 Januari 2021 / Disetujui: 10 Agustus 2021

\begin{abstract}
Longan (Dimocarpus longan L.) is favored by the Indonesian people because it is easy to cultivate and has a sweet fruit taste, contains high water content and has good nutritional value. The aim of this research was to study the effect of rootstock height and variety on shoot graft on the percentage of longan growth. The research method used a randomized block treatment design with 2 types of treatment, namely rootstock height, there were 3 levels of $15 \mathrm{~cm}, 20 \mathrm{~cm}, 25 \mathrm{~cm}$ ) and various kinds of varieties (new crystal, diamond river, matalada). Parameters measured were number of shoots, number of leaves, length of stems, percentage of success. The results showed that the treatment of rootstock height T3 with a length of $25 \mathrm{~cm}$ influenced the development of 8 weeks, the number of leaves 33, 22, the number of shoots 4.35, the length of the stem $8.35 \mathrm{~cm}$ and the percentage of longan growth was $79 \%$ the best. Treatment of varieties did not significantly affect all parameters and there was no interaction between rootstock height and variety at shoot graft on longan growth percentage.
\end{abstract}

Keywords: rootstock, various varieties, top connectivity.

\section{ABSTRAK}

Tanaman Kelengkeng (Dimocarpus longan L. ) digemari masyarakat Indonesia karena mudah dibudidayakan dan rasa buah manis, mengandung kadar air tinggi serta memiliki nilai gizi yang baik. Penelitian bertujuan mempelajari pengaruh tinggi batang bawah dan macam varietas pada sambung pucuk terhadap persentase tumbuh kelengkeng. Metode Penelitian menggunakan Rancangan Perlakuan Acak Kelompok dengan 2 jenis perlakuan yaitu Tinggi batang bawah ada 3 level $15 \mathrm{~cm}$, $20 \mathrm{~cm}, 25 \mathrm{~cm}$ ) dan Macam Varietas (new kristal, diamond river, matalada). Parameter yang diukur adalah jumlah tunas, jumlah daun, panjang batang, persentase keberhasilan. Hasil penelitian menunjukkan perlakuan tinggi batang bawah T3 yang panjangnya $25 \mathrm{~cm}$ memepangaruhi perkembangan 8 minggu jumlah daun 33, 22 helai, jumlah tunas 4,35, panjang batang $8,35 \mathrm{~cm}$ dan persentase pertumbuhan kelengkeng sebesar $79 \%$ yang paling baik. Perlakuan macam varietas tidak berpengaruh nyata terhadap semua parameter dan tidak terjadi interaksi antara tinggi batang bawah dan macam varietas pada sambung pucuk terhadap persentase tumbuh kelengkeng.

Kata kunci: batang bawah, macam varietas, sambung pucuk.

\section{PENDAHULUAN}

Tanaman kelengkeng (Dimocarpus longan Lour.) digemari masyarakat Indonesia, karena rasanya manis mudah dibudidayakan karena daya adaptasinya luas dapat hidup di dataran tinggi juga rendah. Perbungaan dipengaruhi iklim dan curah hujan (Hendrawan, 2013). Menurut (Tyas et al, 2013). tanaman kelengkeng daging buahnya berbentuk bulat, memiliki kadar air yang tinggi, warnanya putihbening.Daging buah kelengkeng mengandung protein (nabati), lemak sukrosa, glukosa, vitamin A, vitamin B (Faizah dkk., 2012). Budidaya tanaman kelengkeng yaitu secara vegetatif seperti sambung pucuk, okulasi, stek, cangkok dan perbanyakan generatif . Perbanyakan vegetatif pada tanaman kelengkeng dengan sambung pucuk mempunyai tingkat keberhasilan lebih tinggi dibandingkan dengan okulasi. (Al, 2016). Hal ini didukung pendapat (Wisahya, 2011) bahwa teknik sambung pucuk merupakan metode menyambungkan batang bawah dan batang atas dengan tujuan produktivitas lebih cepat jangka waktu 2 tahun.

Permasalahan petani kelengkeng jika menanam keengkeng yang berasal dari biji bebuah lama sekali serta belum tentu hasilnya sama dengan induknya. Berdasarkan kenyataan tersebut maka perlu inovasi baru tentang perbanyakan tanaman menggunakan vegetatif buatan. Ada 5 metode tehnik penyambungan yaitu menempel, penyambungan, penyusuan, pencangkokan dan stek (Prastowo et al, 2006). Menurut Riady dan Sumeru, (2017), sambung pucuk menggunakan tinggi batang bawah $10 \mathrm{~cm}$, $20 \mathrm{~cm}$, dan $30 \mathrm{~cm}$ menyatakan bahwa perlakuan tinggi batang bawah $30 \mathrm{~cm}$ yang terbaik meningkatkan persentase 
keberhasilan sambung pucuk Kelengkeng kristal (Dimocarpus longan Lour). Cara bertanam Kelengkeng Kristal juga dapat dilakukan dalam Pot istilah Tabulampot Kelengkeng Kristal (Higaragro, 2015). Penelitian ini bertujuan untuk Mengetahui interaksi antara tinggi batang bawah dan macam varietas pada sambung pucuk terhadap persentase tumbuh kelengkeng (Dimocarpus longan Lour.). Rancangan percobaan yang digunakan adalah rancangan acak kelompok secara faktorial. Perlakuan penelitian ada 2 jenis yaitu pengaruh tinggi batang bawah dan macam varietas. Parameter yang diukur meliputi jumlah daun, tinggi batang, jumlah tunas, persentase keberhasilan. Hasil penelitian merupakan penemuan yang bersifat novelty yang belum pernah dilaporkan dalam jurnal nasional maupun internasional dan diharapkan dapat bermanfaat.

\section{BAHAN DAN METODE}

Penelitian ini dilaksanakan di Agrotama Armada berlokasi di Jalan Raya Silir RT. 07 RW. 02, Desa Silir, Kecamatan Wates, Kabupaten Kediri, Jawa Timur. Penelitian ini dilakasanakan pada bulan 12 Juni sampai 29 Agustus 2020. Ketinggian 65 meter di atas permukaan laut yang terletak di ruang sungkup pembibitan. Suhu $25^{\circ} \mathrm{C}$. Alat yang digunakan dalam penelitian ini antara lain : pisau okulasi / cutter, gunting, tali pengikat, plastik sungkup, penggaris, label penelitian, alat tulis dan alat dokumentasi. Bahan yang digunakan dalam penelitian ini anatara lain :batang bawah yang berasal dari biji setelah semai berumur 3 bulan, dan batang atas yang terdiri dari varietas Diamond River, Matalada dan New Kristal yang diambil dari pohon induk yang sehat. Batang atas diperoleh dari UD. Agrotama Armada. Penelitian ini menggunakan Rancangan Acak Kelompok (RAK) dengan dua faktor, yakni faktor pertama adalah tinggi batang bawah yang terdiri dari 3 level dan faktor kedua adalah macam varietas tanaman kelengkeng yang terdiri dari 3 level. Kedua faktor diulang sebanyak 3 kali sehingga didapatkan 27 plot percobaan. Setiap plot terdiri dari 10 tanaman.Faktor 1 : Tinggi batang bawah (T) yang terdiri dari 3 level :T1 = Tinggi Batang Bawah $15 \mathrm{~cm}$, $\mathrm{T} 2$ = Tinggi Batang Bawah $20 \mathrm{~cm}, \mathrm{~T} 3$ = Tinggi Batang Bawah $25 \mathrm{~cm}$. Faktor 2 : Varietas tanaman kelengkeng (V) yang terdiri dari 3 level :V1 = Varietas New Kristal, V2 = Varietas Diamond River, V3 = Varietas Matalada

Pelaksanaan Penelitian

\section{Penyiapan Bibit Batang Bawah Kelengkeng}

Bibit kelengkeng yang digunakan sudah berumur 3 bulan dan merupakan bibit yang ditanam dari biji dipilih ukuran diameter batang sama atau seragam varietasnya.

\section{Pemilihan Batang Atas}

Batang atas yang digunakan diambil dari pohon indukan yang sudah jelas varietasnya. Diameter batang atas diusahakan sama besar dengan diameter batang bawah. Pilih batang bawah yang tidak terlalu muda atau tidak terlalu tua sekitar umur 3-4 bulan.

\section{Pelaksanaan Sambung Pucuk}

Menyiapkan alat-alat dan bahan seperti batang atas, batang bawah, pisau okulasi, gunting, tali pingikat, penggaris, label penelitian, alat tulis dan dokumentasi. Langkah-langkah sambung pucuk sebagai berikut :

1. Potong bibit batang bawah sesuai dengan perlakuan yang diinginkan.

2. Sayat ujung batang bawah kearah bawah hingga membentuk celah menyerupai huruf (V) sepanjang 2-3 cm.

3. Runcingkan/sayat dasar entres pada kedua sisi yang berhadapan sepanjang 1-3 cm hingga membentuk baji (pahat).

4. Sisipkan batang atas kedalam batang bawah sampai benar-benar menyatu lalu ikat bagian sambungan tersebut dengan tali yang sudah disiapkan.

5. Sungkup bibit yang telah disambung dengan kantong plastik transparan untuk menjaga kelembapan (Sunarjono, 2010),

\section{Variabel Pengamatan}

1. Jumlah Tunas

2. Jumlah Daun

3. Panjang Batang

4. Persentase Keberhasilan Sambung Pucuk (\%)

\section{Analisis Data}

Data hasil pengamatan pada variabel dimasukan kedalam tabel untuk dilakukan uji F dengan metode Sidik Ragam (ANOVA), apabila kombinasi perlakuan terjadi interaksi nyata atau sangat nyata dari masing-masing perlakuan, dilakukan uji perbandingan menggunakan uji BNT dengan taraf 5\% (Utomo, 2018).

\section{HASIL DAN PEMBAHASAN}

\section{Jumlah Daun (helai)}

Berdasarkan data sidik ragam pada Tabel 1. pada pengamatan jumlah daun tidak terjadi interaksi pada perlakuan tinggi batang bawah dan varietas tanaman kelengkeng. Pada perlakuan tunggal penggunaan tinggi batang bawah berpengaruh nyata pada parameter jumlah daun pada fase vegetatif, sedangkan pada perlakuan tunggal varietas tanaman kelengkeng tidak berpengaruh nyata.

Hasil uji lanjut BNT 5\% (Tabel 1), menunjukkan bahwa pengamatan jumlah daun pada tinggi batang bawah terbanyak dihasilkan oleh perlakuan T3 $(25 \mathrm{~cm})$ sebesar 22,75 helai, 26,76 helai, 31,36 helai, 31,57 helai, 33,22 helai.komponen yang sangat penting dalam proses fotosintesis pada tanaman yaitu daun. Pada pertumbuhan awal tanaman masih belum mampu memproduksi karbohidrat secara normal. Disamping itu, perbedaan panjang batang atas juga sangat mempengaruhi proses pembentukan daun ( Rahmatika dan Setyawan. 2019). 
Tabel 1. Pengamatan jumlah daun tanaman kelengkeng

\begin{tabular}{lcccccc}
\hline \multirow{2}{*}{ Perlakuan } & \multicolumn{5}{c}{ Jumlah Duan (Helai) } \\
\cline { 2 - 7 } & $3 \mathrm{MSS}$ & $4 \mathrm{MSS}$ & $5 \mathrm{MSS}$ & $6 \mathrm{MSS}$ & 7 MSS & 8 MSS \\
\hline T1 & 10,25 & $12,56 \mathrm{a}$ & $13,97 \mathrm{a}$ & $16,60 \mathrm{a}$ & $16,85 \mathrm{a}$ & $19,29 \mathrm{a}$ \\
T2 & 15,67 & $21,65 \mathrm{~b}$ & $25,51 \mathrm{~b}$ & $30,28 \mathrm{~b}$ & $30,52 \mathrm{~b}$ & $32,99 \mathrm{~b}$ \\
T3 & 15,23 & $22,75 \mathrm{~b}$ & $26,76 \mathrm{~b}$ & $31,36 \mathrm{~b}$ & $31,57 \mathrm{~b}$ & $33,22 \mathrm{~b}$ \\
\hline BNT 5\% & th & 6,88 & 7,86 & 9,40 & 9,60 & 10,81 \\
\hline V1 & 13,89 & 18,32 & 20,86 & 24,61 & 24,86 & 28,17 \\
V2 & 13,56 & 19,32 & 22,49 & 25,97 & 26,10 & 27,31 \\
V3 & 13,70 & 19,33 & 22,90 & 27,66 & 27,97 & 30,03 \\
\hline BNT 5\% & tn & tn & tn & tn & tn & tn \\
\hline
\end{tabular}

Keterangan: Angka yang diikuti oleh huruf yang sama pada kolom yang sama tidak berbeda nyata pada taraf uji Beda Nyata Terkecil pada taraf 5\%.

Tabel 2. Jumlah tunas tanaman kelengkeng

\begin{tabular}{|c|c|c|c|c|c|c|}
\hline \multirow{2}{*}{ Perlakuan } & \multicolumn{6}{|c|}{ Jumlah Tunas } \\
\hline & $3 \mathrm{MSS}$ & $4 \mathrm{MSS}$ & $5 \mathrm{MSS}$ & $6 \mathrm{MSS}$ & $7 \mathrm{MSS}$ & $8 \mathrm{MSS}$ \\
\hline $\mathrm{T} 1$ & $1,03 \mathrm{a}$ & $1,43 \mathrm{a}$ & 1,97 & $1,96 \mathrm{a}$ & $1,99 \mathrm{a}$ & $2,62 \mathrm{a}$ \\
\hline $\mathrm{T} 2$ & $1,58 \mathrm{a}$ & $2,55 \mathrm{~b}$ & 2,87 & $3,27 \mathrm{~b}$ & $3,37 \mathrm{~b}$ & $4,05 \mathrm{a}$ \\
\hline $\mathrm{T} 3$ & $1,79 \mathrm{~b}$ & $2,70 \mathrm{~b}$ & 2,97 & $3,40 \mathrm{~b}$ & $3,58 \mathrm{~b}$ & $4,35 \mathrm{~b}$ \\
\hline BNT 5\% & 0,58 & 0,83 & tn & 1,09 & 1,09 & 1,43 \\
\hline V1 & 1,48 & 2,26 & 2,79 & 2,90 & 2,97 & 3,72 \\
\hline $\mathrm{V} 2$ & 1,38 & 2,12 & 2,43 & 2,69 & 2,75 & 3,57 \\
\hline V3 & 1,54 & 2,30 & 2,59 & 3,04 & 3,21 & 3,73 \\
\hline BNT 5\% & tn & tn & tn & tn & tn & tn \\
\hline
\end{tabular}

Keterangan: Angka yang diikuti oleh huruf yang sama pada kolom yang sama tidak berbeda nyata pada taraf uji Beda Nyata Terkecil pada taraf $5 \%$.

$\underline{\text { Tabel 3. Panjang batang tanaman kelengkeng }}$

\begin{tabular}{lcccccc}
\hline & \multicolumn{5}{c}{ Panjang Batang $(\mathrm{cm})$} \\
\cline { 2 - 7 } Perlakuan & $3 \mathrm{MSS}$ & $4 \mathrm{MSS}$ & $5 \mathrm{MSS}$ & $6 \mathrm{MSS}$ & 7 MSS & $8 \mathrm{MSS}$ \\
\hline T1 & $3,21 \mathrm{a}$ & $3,39 \mathrm{a}$ & $3,39 \mathrm{a}$ & $3,53 \mathrm{a}$ & $3,49 \mathrm{a}$ & $4,18 \mathrm{a}$ \\
T2 & $6,38 \mathrm{~b}$ & $6,39 \mathrm{~b}$ & $6,47 \mathrm{~b}$ & $6,52 \mathrm{~b}$ & $6,69 \mathrm{~b}$ & $7,49 \mathrm{~b}$ \\
T3 & $6,90 \mathrm{~b}$ & $6,91 \mathrm{~b}$ & $7,22 \mathrm{~b}$ & $7,47 \mathrm{~b}$ & $7,53 \mathrm{~b}$ & $8,32 \mathrm{~b}$ \\
\hline BNT 5\% & 1,75 & 1,87 & 1,81 & 1,90 & 1,89 & 9,07 \\
\hline V1 & 5,39 & 5,59 & 5,68 & 5,84 & 5,91 & 6,72 \\
V2 & 5,53 & 5,69 & 5,70 & 5,88 & 5,91 & 6,68 \\
V3 & 5,57 & 5,41 & 5,70 & 5,80 & 5,89 & 6,59 \\
\hline BNT 5\% & tn & tn & tn & tn & tn & tn \\
\hline
\end{tabular}

Keterangan: Angka yang diikuti oleh huruf yang sama pada kolom yang sama tidak berbeda nyata pada taraf uji Beda Nyata Terkecil pada taraf $5 \%$.

Menurut pendapat Firman dan Ruskandi, (2009) menjelaskan bahwa jumlah daun akan menjadi banyak apabila kualitas sambungan baik karena telah menyatu dengan sempurna. Pada umur 3 minggu tidak berpengaruh nyata diduga karena kelembapan yang terlalu tinggi sehingga mengakibatkan sambungan tidak menyatu dengan sempurna. Menurut pendapat Persaulian etal., (2012) menyebutkan kelembapan tinggi mengakibatkan sambungan basah, hal ini berpengaruh terhadap pertumbuhan, terutama pada perkembangan sel. Perlakuan varietas tanaman pada sambung pucuk kelengkeng pada semua umur pengamatan tidak berpengaruh nyata. Penyebabnya karena ada perbedaan sifat genetik setiap varietas berbeda-beda (Sudjijo, 2009). Kemungkinan karena kemampuan suatu varietas dalam beradaptasi terhadap lingkungan dan pengelolaan tanaman yang kurang optimum (Simatu pang et. al 2004). 
Tabel 4. Persentase keberhasilan Sambung Pucuk tanaman kelengkeng

\begin{tabular}{|c|c|}
\hline Perlakuan & Persentase keberhasilan (\%) pada umur 8 MSS \\
\hline T1 & $33 \mathrm{a}$ \\
\hline $\mathrm{T} 2$ & $77 \mathrm{~b}$ \\
\hline $\mathrm{T} 3$ & $79 \mathrm{~b}$ \\
\hline BNT 5\% & 0,22 \\
\hline V1 & 53 \\
\hline $\mathrm{V} 2$ & 70 \\
\hline V3 & 66 \\
\hline BNT 5\% & tn \\
\hline
\end{tabular}

Keterangan: Angka yang diikuti oleh huruf yang sama pada kolom yang sama tidak berbeda nyata pada taraf uji Beda Nyata Terkecil pada taraf $5 \%$.

\section{Jumlah Tunas Tumbuh}

Berdasarkan pada pengamatan jumlah tunas yaitu tidak ada interaksi pada perlakuan tinggi batang bawah dan macam varietas. Pada perlakuan tinggi batang bawah berpengaruh nyata pada parameter jumlah tunas sedangkan pada perlakuan macam varietas tanaman tidak berpengaruh nyata, disajikan pada Tabel 2.

Berdasarkan hasil uji lanjut BNT 5\% (Tabel 2), menunjukkan bahwa pengamatan jumlah tunas pada perlakuan tinggi batang bawah tanaman kelengkeng berbeda nyata pada umur 3, 6, 7 dan 8 MSS (minggu setelah sambung) dan berbeda sangat nyata pada umur 4 MSS (minggu setelah sambung), perlakuan T3 $(25 \mathrm{~cm})$ dengan jumlah tunas terbanyak pada setiap umur pengamatan yaitu 1,79 tunas, 2,70 tunas, 2,97 tunas, 3,40 tunas, 3,58 tunas, 4,35 tunas. Lakitan, (2003) menerangkan bahwa perlakuan panjang batang bawah bisa meningkatkan pertumbuhan panjang tunas karena terdapat hormon auksin dan sitokinin endogen berpengaruh terhadap proses pembelahan sel serta perpanjangan sel. Rerata jumlah tunas pada perlakuan tunggal varietas tanaman kelengkeng pada semua umur pengamatan tidak berpengaruh nyata. Hal ini disebabkan karena adanya perbedaan sifat genetik pada jenis varietas berbeda (Sudjijo, 2009).

\section{Panjang Batang}

Pengamatan panjang batang menunjukan tidak terdapat interaksi pada kedua perlakuan yaitu tinggi batang bawah dan jenis varietas tanaman kelengkeng. Pada perlakuan tinggi batang bawah berpengaruh nyata pada parameter panjang batang pada fase vegetatif, sedangkan pada perlakuan macam varietas tidak ada pengruh yang nyata pada parameter panjang batang, data tersebut diihat pada Tabel 3 .

Berdasarkan Tabel 3, menunjukkan analisa panjang batang pada perlakuan tunggal tinggi batang bawah tanaman kelengkeng berbeda nyata pada umur 3 MSS (minggu setelah sambung) dan berbeda sangat nyata umur 4 MSS sampai 8 MSS (minggu setelah sambung). Rerata panjang batangtertinggi dihasilkan oleh perlakuan $\mathrm{T} 3(25 \mathrm{~cm})$ yaitu
6,90 cm, 6,91 cm, 7,22 cm, 7,47 cm, 7,53 cm, 8,32cm. Pendapat (Lakitan, 2001 dalam Putri et al. 2016) bahwa senyawa sitokinin merangsang terjadinya pembelahan sel dengan meningkatkan proses sintesa protein, dan auksin akan memacu pemanjangan sel. Perlakuan macam varietas tanaman kelengkeng pada semua umur pengamatan tidak berpengaruh nyata.

\section{Persentase Keberhasilan (\%)}

Analisa persentase keberhasilan menunjukkan tidak terjadi interaksi yang nyata pada perlakuan tinggi batang bawah dan varietas tanaman kelengkeng. Pada perlakuan tunggal tinggi batang bawah berpengaruh nyata pada parameter persentase keberhasilan pada fase vegetatif, sedang pada perlakuan macam varietas tidak berpengaruh nyata, seperti pada Tabel 4. Berdasar uji lanjut BNT 5\% rerata persentase keberhasilan pada perlakuan tunggal tinggi batang bawah pada tanaman kelengkeng tertinggi dihasilkan T3 $(25 \mathrm{~cm})$ dengan persentase keberhasilan sebanyak $79 \%$.

Hal ini sesuai dengan pendapat Winarno, (2009) menjelaskan pada perlakuan panjang batang bawah mendukung persentase sambung jadi dikarenakan cadangan makanan lebih banyak dibanding dengan panjang batang bawah yang lebih pendek, sehingga proses pembesaran , diferensiasi sel akan lebih baik. selain untuk pembentukan kalus hingga terbentuk jaringan pembuluh dan untuk meningkatkan kelangsungan hidup tanaman. Rerata macam varietas tanaman kelengkeng pada semua umur pengamatan tidak berpengaruh nyata. Rerata panjang batang terbanyak dihasilkan oleh perlakuan V2 (Diamond River). Hal ini diduga disebabkan karena kecocokan antara batang bawah dan batang atas merupakan syarat utama untuk memperoleh bibit dengan pertumbuhan yang baik. Ada beberapa tingkat ketidakcocokan pada penyambungan batang bawah dan batang atas. Pertama adalah ketidakcocokan pada penyambungan karena sama sekali tidak cocok, dalam artian sambungan pernah bertaut atau saling menolak. Pada kasus kedua, batang atas dan batang bawah saling bertaut, tetapi tidak sempurna sehingga pertumbuhan bibit tidak sempurna. Entres yang kurang baik sangat mempengaruhi kecocokan 
antara batang atas dan batang bawah (Fuller, 2005 dalam Putri et al. 2016).

\section{KESIMPULAN}

Hasil penelitian pengaruh tinggi batang dan macam varietas terhadap persentase tumbuh kelengkeng 8 minggu setelah sambung pucuk adalah perlakuan tinggi batang bawah T3 yang panjangnya $25 \mathrm{~cm}$ mempangaruhi perkembangan jumlah daun, jumlah tunas, panjang batang dan persentase pertumbuhan kelengkeng yang paling baik, tidak terjadi interaksi antara tinggi batang bawah dan macam varietas pada sambung pucuk terhadap persentase tumbuh kelengkeng. Perlakuan macam varietas tidak berbeda nyata terhadap semua parameter dan persentase tumbuh.

\section{DAFTAR PUSTAKA}

Al, F. B. (2016). Teknik. Perbanyakan Tanaman Lengkeng Dengan Sambung Pucuk. http://balitjestro.litbang.pertanian.go.id/teknikperbanyakan-tanaman-lengkeng-dengan-sambungpucuk/(Diakses pada tanggal 23 Februari 2020).

Faizah, N., S, Fatimah, dan I., Ardasania. (2012). Taksonomi Tumbuhan Tinggi. Jurusan Biologi Fakultas Sains dan Teknologi. Universitas Islam Negeri Maulana Malik Ibrahim.

Firman, C., dan Ruskandi. (2009). Teknik Pelaksanaan Percobaan Pengaruh Naungan Terhadap Keberhasilan Penyambungan Tanaman Jambu Mete (Anacardium occidentale L.). Balai Penelitian Tanaman Rempah Dan Aneka Tanaman Industri. Buletin Teknik Pertanian. Sukabumi, 14(1), 27-30.

Hendrawan, I. (2013). Teknologi off-season tanaman lengkeng pada rumah tanaman sebagai upaya memenuhi kebutuhan pasar. E-Journal WIDYA Eksata, 1(1), 20-27.

Firman, C., dan Ruskandi. (2009). Teknik Pelaksanaan Percobaan Pengaruh Naungan Terhadap Keberhasilan Penyambungan Tanaman Jambu Mete (Anacardium occidentale L.). Balai Penelitian Tanaman Rempah dan Aneka Tanaman Industri. Buletin Teknik Pertanian. Sukabumi, 14(1), 27- 30.

Higaragro. (2015). Bibit Tanaman Buah Kelengkeng New
Kristal. https://higaragro.com/product/bibit-tanamanbuah-kelengkeng-new-kristal/. (Diakses pada tanggal 9 April 2020).

Kementan. (2019). Syarat Sambung Pucuk Tanaman Pala. http://cybex.pertanian.go.id/mobile/artikel/82699/Sya rat-Sambung-Pucuk-Tanaman-Pala/. (Diakses pada tanggal 13 Juni 2020).

Lakitan, B. (2003). Dasar-dasar Fisiologi Tumbuhan. PT. Raja Grafindo Persada. Jakarta

Persaulian, T., P. D. Bandem, dan Patriani. (2012). Pengaruh Panjang Entris Terhadap Keberhasilan Sambung Pucuk Bibit Jambu Air, Jurnal Sains Mahasiswa Pertanian. Pontianak, 1(1), 1-9.

Putri, D., H. Gustian dan Y. Suryati. (2016). Pengaruh Panjang Entres Terhadap Keberhasilan Penyambungan Tanaman Alpukat (Persea americana Mill.). Jurnal Agrosains dan Teknologi, 1, 1.

Prastowo, N. H, J. M. Roshetko, G. E. S. Manurung, E. Nugraha, J. M. Tukan., (2006), Teknik Pembibitan Dan Perbanyakan Vegetatif Tanaman Buah, Bogor: World Agroforestry Centre (ICRAF) dan Winrock International.

Riady, S., dan S. Ashari. (2017). Pengaruh Tinggi Batang Bawah Pada Keberhasilan Grafting Dua Jenis Durian (Durio zibethinus Murr.) Lokal Wanosalam Kabupaten Jombang. Jurnal Produksi Tanaman, 5, 10.

Rahmatika, W., dan F. Setyawan. (2019). Kajian Pelestrain Durian Lokal Kediri Melalui Perbanyakan Sistem Grafting. Jurnal Ilmiah Hijau Cendekia, .4 (1), 2327.

Sudjijo. (2009). Pengaruh Ukuran Batang Bawah dan Batang Atas Terhadap Pertumbuhan Durian Monthong, Hepe, dan DCK-01. Jurnal Hortikultura. 19(1), 89-92.

Tyas P. S., D. Setyadi, dan Umiyah. (2013). Perkembangan Pembungaan Lengkeng (Dimocarpus longan Lour) "Diamond River". Jurnal Ilmu Dasar. 14(2), 111120.

Utomo, S. P., (2018). Rancangan Percobaan Agroteknologi. UNISKA Press. Kediri

Wisahya. (2011). Teknik Memperbanyak Tanaman Kakao dan Pemasarannya. Jakarta. 